\title{
Congenital dyserythropoietic anaemia type II (HEMPAS): a family study
}

\author{
SHAUN R MCCANN, R FIRTH, NUALA MURRAY, AND IJ TEMPERLEY \\ From the Departments of Haematology, Federated Dublin Voluntary Hospitals and St James's Hospital, \\ and Department of Biochemistry, Trinity College, Dublin, Ireland
}

SUMMARY A family having two affected siblings with congenital dyserythropoietic anaemia type II (HEMPAS) is described. The proband was diagnosed after referral for investigation of haemolytic anaemia. Clinical evaluation and in vivo red cell (RBC) survival and the sequestration studies in the proband indicated that the anaemia was due to a combination of ineffective erythropoiesis and premature destruction of RBCs in the spleen. Scanning electron microscopic examination of peripheral RBCs was undertaken and is reported. The polypeptide composition of RBC membranes was also examined using polyacrylamide gel electrophoresis after solubilisation in sodium dodecyl sulphate. These results are also reported.

Congenital dyserythropoietic anaemias (CDA) are rare familial disorders characterised by the association of refractory anaemia with multinuclearity and bizarre nuclear abnormalities of erythrocyte precursors in the bone marrow. Three types of CDA are well recognised. ${ }^{1}$ Recently, a new type has been described. ${ }^{2}$ CDA type II has been called HEMPAS ${ }^{3}$ because of the positive acidified serum (Ham) test found in these patients. Other serological abnormalities found in HEMPAS are a high agglutination titre with anti-i, an unusual susceptibility to lysis by anti-i and anti-I, and a negative sucrose lysis test. The aetiology of the disease remains unknown but there is considerable evidence available to suggest a RBC membrane defect. ${ }^{3-5}$ Recently, Vainchenker ${ }^{6}$ has provided evidence that the defect in HEMPAS is due to an abnormal early erythroid precursor and is not the result of an environmental defect in the bone marrow.

\section{Case report}

The proband, GH, a 7-year-old boy, was referred to the haematology department for evaluation of probable haemolytic anaemia. The only prior medical history was that of a heart murmur at the age of 5 years. This was thought to be functional, secondary

Received for publication 14 April 1980

to a severe anaemia. Physical examination revealed a small child with a lemon yellow tinge to his skin. The forehead was prominent and the spleen was palpable $3 \mathrm{~cm}$ below the left costal margin. The liver was palpable $3 \mathrm{~cm}$ below the right costal margin.

Investigations showed haemoglobin $7.5 \mathrm{~g} / \mathrm{dl}$; MCV 80 fl; WBC $8.5 \times 10^{9} / 1$ (normal differential), platelets $280 \times 10^{9} / 1$, reticulocytes $4 \%$. The blood film showed anisocytosis and poikilocytosis, and pincer cells were seen (Fig. 1). Occasional nucleated

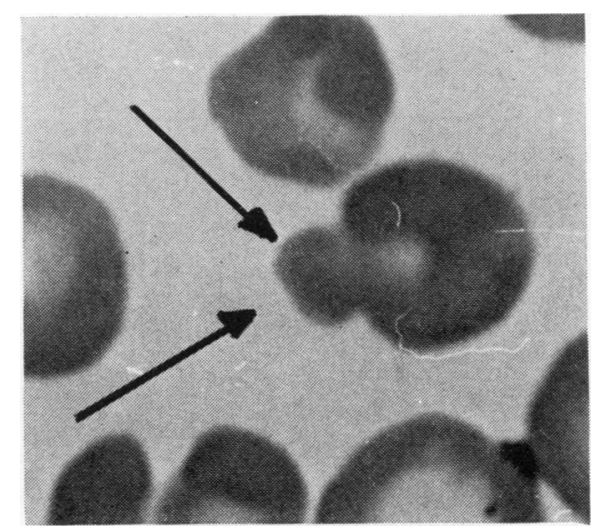

Fig. 1 Peripheral blood showing 'pincer cells' (arrow). Jenner Giemsa × 1000 (oil immersion). 


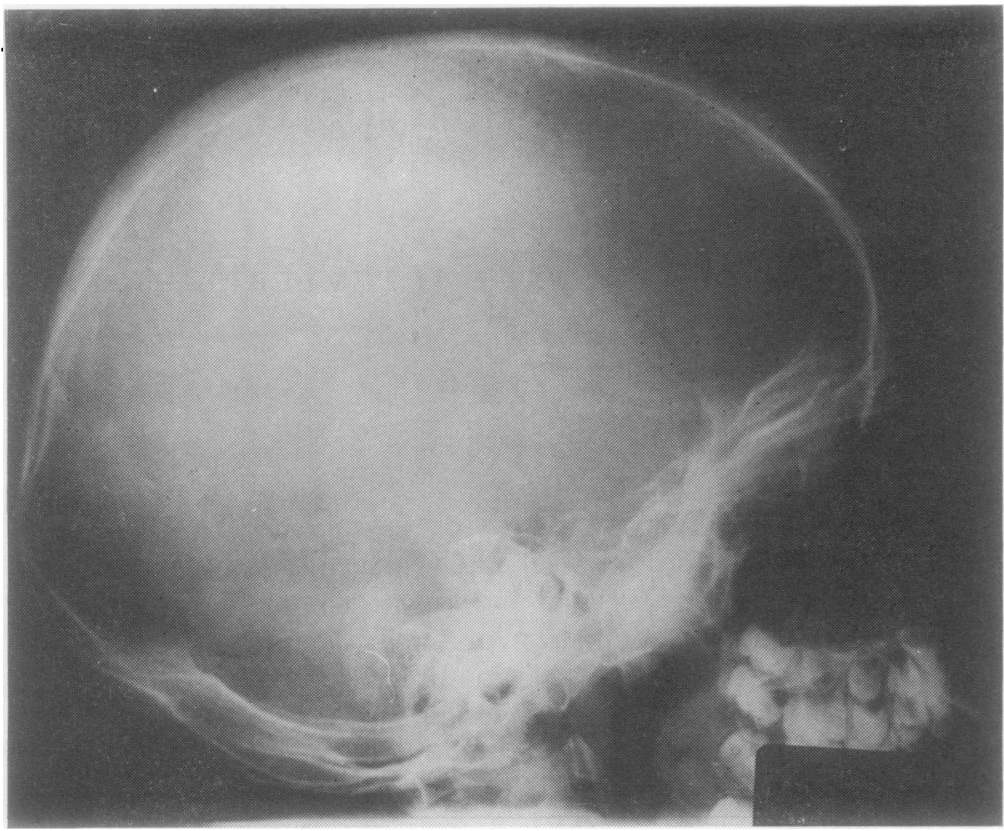

Fig. 2 Skull $\mathrm{x}$-ray showing marked vertical striation of the trabeculae of the vault ('hair on end"). red cells were present. The serum bilirubin was $53 \mu \mathrm{mol} / 1$ and the LDH was 173 IU. Haptoglobins were not detected. The serum $B_{12}$ and folate were normal and the direct antiglobulin test (Coombs) was negative. The serum iron was $36 \mu \mathrm{mol} / \mathrm{l}$ and the TIBC was $38 \mu \mathrm{mol} / \mathrm{l}$. The osmotic fragility curve revealed a tail of slightly resistant red cells. A skull $x$-ray showed well-marked vertical striation of the trabeculae of the skull vault (Fig. 2). The chest $x$-ray was normal. The bone marrow was strikingly abnormal. Erythroid hyperplasia was present, and the majority of late normoblasts showed evidence of multinuclearity. The nuclear configuration was

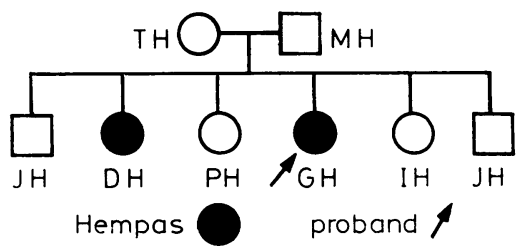

Fig. 3 Family tree showing proband and one affected sibling.

normoblastic however. Erythrophagocytosis was present, and occasional 'Gaucher cells' were seen. A diagnosis of probable CDA type II was made. Serological evaluation showed a positive HAM test with three out of eight compatible sera and the anti-i agglutination titre was $1: 256$ at $20^{\circ} \mathrm{C}$. The patient was transfused with packed red cells.

Detailed red cell studies and a full family investigation were subsequently undertaken. Further evaluation of the family revealed no evidence of parental consanguinity. The patient's five siblings and both parents all had full blood counts, reticulocyte counts, and peripheral blood smears examined. One sibling (DH) (Fig. 3) was found to have splenomegaly and a haemoglobin of $8.2 \mathrm{~g} / \mathrm{dl}$ with reticulocytes $1.0 \%$. The blood film showed poikilocytosis, and the bone marrow appearances were similar to those of the proband. Serological testing gave a positive HAM test with two of six compatible sera, and the anti-i agglutination was elevated (Table 1). The anti-i titre of the father was also abnormal (normal $<1: 8$ ). Fasting lipoprotein profiles were carried out in both affected children and were within normal limits.

\section{Material and methods}

The annual blood consumption was calculated as outlined for patients with thalassaemia. ${ }^{7}$ Red cell survival and sequestration studies using $\mathrm{Na}_{2}{ }^{51} \mathrm{CrO}_{4}$ (sodium chromate) were performed using standard techniques. ${ }^{8} 9$

SCANNING ELECTRON MICROSCOPY (SEM)

Venous blood was taken without an anticoagulant and added dropwise immediately to a large volume 
Table 1 Anti-i agglutination titre at $20^{\circ} \mathrm{C}$

\begin{tabular}{llll}
\hline TH father & MH mother & GH proband & $\begin{array}{l}\text { DH } \\
\text { affected } \\
\text { sibling }\end{array}$ \\
\hline $1: 32$ & Nil & $1: 256$ & $1: 256$ \\
\hline
\end{tabular}

of $3 \%$ glutaraldehyde, which was constantly shaken. The sample was then processed, as described by Bessis $^{10}$ and examined using an MSM-5 mini SEM.

\section{RED CELL MEMBRANES}

Venous blood was taken into lithium heparin and processed within 1 hour. Red cell ghosts were prepared, ${ }^{11}$ and electrophoresis after solubilisation in sodium dodecyl sulphate was carried out on a $10 \%$ polyacrylamide gel (PAGE SDS). ${ }^{12}$ The gels were stained with Coomassie brilliant blue R.250.13 The peptide profiles of patients and normal controls were analysed with respect to standard published profiles. ${ }^{14}$

\section{SEROLOGY}

Anti-i agglutination titres were performed at $20^{\circ} \mathrm{C}$ using washed red cells by Dr S Worlledge, Royal Postgraduate Medical School, London.

\section{Results}

Annual blood consumption by the proband was $270 \mathrm{ml} / \mathrm{kg}$ per year to give a mean haemoglobin of $9.7 \mathrm{~g} / \mathrm{dl}$. The expected blood consumption in thalassaemia major for a similar mean haemoglobin would be $220 \mathrm{ml}$ or less.?

The red cell survival was reduced (Table 2), and there was evidence of some excess splenic sequestration.

\section{SCANNING ELECTRON MICROSCOPY}

SEM revealed two populations of red cells. The majority of RBC appeared morphologically normal, and a minority (approximately $10 \%$ ) showed cytoplasmic projections (Fig. 4), which presumably correspond with the pincer cells seen under light microscopy.

PAGE SDS

Red cell membrane profiles from the proband were

Table 2 Red cell survival

\begin{tabular}{llllll}
\hline & $\begin{array}{l}M R C L \\
(\text { days })\end{array}$ & $\begin{array}{l}T_{\text {so }} C r \\
(\text { days })\end{array}$ & SEI \% & LEI \% & SLI \% \\
\hline GH & 34 & 17 & 41 & $1 \cdot 21$ & $1 \cdot 17$ \\
Normal & $70-150$ & $25-32$ & $1 \cdot 1-28 \cdot 7$ & $-1 \cdot 4-10 \cdot 2$ & $0.01-0.59$ \\
\hline
\end{tabular}

MRCL $=$ mean red cell life $; T_{s 0} \mathrm{Cr}=$ red cell half life; $\mathrm{SEI}=$ spleen excess index; LEI = liver excess index; SLI = spleen liver index.

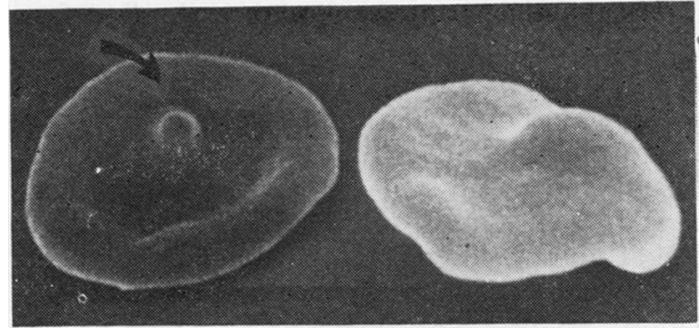

Fig. 4 SEM. Peripheral blood showing cytoplasmic projection.

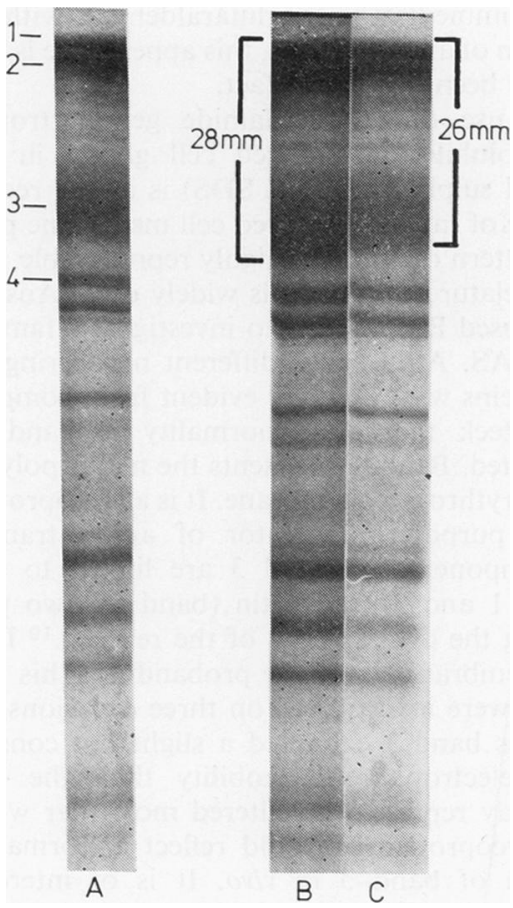

Fig. 5 PAGE SDS $10 \%$ stained with Coomassie brilliant blue R.250 (bands 1 and 2 Spectrin). $A=$ normal control (bands numbered according to Steck); $B=$ proband; $C=$ normal control. Band 3 has a slightly faster electrophoretic mobility than the control.

compared with normal controls (Fig. 5). Band 3 had a faster electrophoretic mobility than the control.

\section{Discussion}

There is considerable evidence that a membrane defect is present in erythrocytes of patients with HEMPAS. Abnormal binding of anti-i and increased lysis with anti-i and anti-I together with a positive Ham test with compatible sera may all result from 
abnormal antigen expression on the red cell surface. Increased binding of anti-i has also been demonstrated in presumed heterozygotes (parents or children of affected individuals), ${ }^{3}$ and in our family the father's red cells bound increased amounts of anti-i.

Light microscopy of peripheral blood shows marked poikilocytosis, and many investigators ${ }^{6}$ 15-17 have demonstrated excessive endoplasmic reticulum beneath the red cell membrane in normoblasts and mature erythrocytes. Our SEM study shows abnormal erythrocyte cytoplasmic projections, and this presumably accounts for the poikilocytes (pincer cells) seen on light microscopy. As the cells were added immediately to glutaraldehyde without the addition of anticoagulant, this appearance is unlikely to have been due to artefact.

The use of polyacrylamide gel electrophoresis after solubilisation of red cell ghosts in sodium dodecyl sulphate (PAGE SDS) is a well recognised method of investigating red cell membrane proteins. The pattern obtained is highly reproducible, and the nomenclature of Steck ${ }^{14}$ is widely used. Anselstetter et $a .^{5}$ used PAGE SDS to investigate a family with HEMPAS. Although a different numbering system of proteins was used it is evident from comparisons with Steck that an abnormality in band 3 was postulated. Band 3 represents the major polypeptide in the erythrocyte membrane. It is a glycoprotein and is the purported mediator of anion transport. ${ }^{18}$ Subcomponents of band 3 are linked to spectrin (bands 1 and 2) and actin (band 5), two proteins forming the cytoskeleton of the red cell. ${ }^{19}$ Erythrocyte membranes from the proband and his affected sibling were investigated on three occasions, and in all cases band 3 exhibited a slight but consistently faster electrophoretic mobility than the control. This may represent an altered molecular weight of this glycoprotein or could reflect abnormal glycosylation of band 3 in vivo. It is of interest that Childs et al. ${ }^{20}$ reported the presence of blood group I activity associated with band 3 .

The red cell abnormality in HEMPAS gives rise to marked ineffective erythropoiesis. ${ }^{21}$ If the disease presents in childhood then skeletal abnormalities such as thickening of the diploë of the skull and perpendicular striations between the tables occur and may give rise to the so-called 'hair on end' radiological appearances.

Barosi et al. ${ }^{22}$ indicated that in some patients there may be a combination of shortened red cell survival together with ineffective erythropoiesis. In our proband, the red cell survival was shortened, and evidence of excessive splenic destruction was present. Modell ${ }^{7}$ studied a large number of thalassaemic patients and indicated that the annual blood consumption for patients with ineffective erythropoiesis could be estimated for a given mean haemoglobin value. A consumption in excess of the predicted figure was evidence of hypersplenism. Using these figures as a model for HEMPAS, the proband had an annual blood consumption slightly in excess of the predicted value. This would be in keeping with the modest reduction in red cell survival and slight excess splenic sequestration.

This family study is the first to be reported in Ireland. Although evidence suggests a red cell membrane defect the aetiology of the disease remains unknown. Further investigation of the cytoskeletal membrane proteins using more sophisticated techniques may help to elucidate the aetiology of this uncommon disease and to clarify whether the electrophoretic abnormalities of band 3 represent an alteration in the polypeptide composition or carbohydrate components of the major intrinsic protein of the erythrocyte membrane.

We thank Dr Anne O'Meara, Our Lady's Hospital for Sick Children, Crumlin, Dublin for referring the proband for investigation; Dr S Worlledge, Royal Postgraduate Medical School, London, for kindly carrying out the anti-i agglutination titres; Miss Margaret Milner for typing the manuscript; and $\mathrm{Mr} \mathbf{P}$ Walsh for technical assistance with the scanning electron microscopy.

This work was supported in part by the Medical Research Council of Ireland.

\section{References}

${ }^{1}$ Williams JW, Beutler E, Erslev A, Rundles RW. In Hematology. McGraw-Hill 1977;427-31.

${ }^{2}$ Sansone G. A new type of congenital dyserythropoietic anaemia. Br J Haematol 1968;39:537-43.

${ }^{3}$ Crookston JH, Crookston C, Rosse WF. Red-cell abnormalities in HEMPAS (hereditary erythroblastic multinuclearity with a positive acidified-serum test). $\mathrm{Br} J$ Haematol 1972;23 (Suppl) :83-91.

${ }^{4}$ Rochant H, N'Go, Minh M, Ton That H, Henri A, Basch A, Sultan C, Dreyfus B. Un nouveau cas de dyserythropoïèse congénital de type II. Caractères immunologiques et transmission héréditaire de l'antigène de polyagglutinabilité distinct des antigènes $\mathrm{T}$, Tn et Cad. Nouv Rev Fr Hématol 1973;13:649-60.

${ }^{5}$ Anselstetter V, Horstmann HJ, Heimpel H. Congenital dyserythropoietic anaemia, types I and II: Aberrant pattern of erythrocyte membrane proteins in CDA II, as revealed by two-dimensional polyacrylamide gel electrophoresis. Br J Haematol 1977;35:209-15.

${ }^{6}$ Vainchenker W, Guichard J, Breton-Gorius J. Morphological abnormalities in cultured erythroid colonies (BFU-E) from the blood of two patients with HEMPAS. Br J Haematol 1979;42:363-9.

7 Modell B. Total management of thalassaemia major. Arch Dis Child 1977;52:489-500.

${ }^{8}$ Lewis, SM, Szur L, Dacie JU. The pattern of erythrocyte destruction in haemolytic anaemia studied with radioactive chromium. Br J Haematol 1960;6:122-30. 
${ }^{9}$ Von Dem Borne AEG Kr, Engelfriet CP, Reynierse E, Beckers D, Van Loghem JJ. Auto-immune haemolytic anaemia. VI ${ }^{51}$ Chromium survival studies in patients with different kinds of warm autoantibodies. Clin Exp Immunol 1973;13:561-71.

${ }^{10}$ Bessis M. In Living Blood Cells and their Ultrastructure. Berlin: Springer-Verlag, 1973;673-746.

${ }^{11}$ Dodge JT, Mitchell C, Hanahan DJ. The preparation and chemical characteristics of haemoglobin-free ghosts of human erythrocytes. Arch Biochem Biophys 1963;100: 119-30.

${ }^{12}$ Laemmli UK. Cleavage of the structural proteins during the assembly of the head of bacteriophage T. Nature 1970;227:681-4.

${ }^{13}$ Fairbanks G, Steck TL, Wallach DFH. Electrophoretic analysis of the major polypeptides of the human erythrocyte membrane. Biochemistry 1971;10:2606-17.

14 Steck TL. The organisation of proteins in the human red blood cell membrane. J Cell Biol 1974;62:1-19.

15 Vernilghen RL, Tan P, Wolf-Peeters C, Broeckaert-Van Orshoven A, Lenwagie AC. Cell membrane anomaly impeding cell division. Experimentia 1971;27:1467-8.

16 Wong KY, Hug G, Lampkin BC. Congenital dyserythropoietic anaemia type II. Ultrastructural and autoradiographic studies of blood and bone marrow. Blood 1972;39:23-30.
${ }^{17}$ Breton-Gorius J, Daniel MT, Cauvel JP, Dreyfus B. Anomalies ultrastructurales des erthroblastes et des erythrocytes dans dix cas de dyserythropoiese congenitale. Nouvelle Revue Francaise d'Hematologie 1973;13:23-49.

${ }^{18}$ Steck TL. The band 3 protein of the human red cell membrane: a review. Supramol Struct 1978;8:311-24.

19 Bennett V, Stenbuck PJ. The membrane attachment protein for spectrin is associated with band 3 in human erythrocyte membranes. Nature 1979;280:468-73.

${ }^{20}$ Childs RA, Feizi T, Fukuda M, Hakomori S-L. Blood group-I activity associated with band 3 , the major intrinsic membrane protein of human erythrocytes. Biochem J 1978;173:333-6.

21 Vernilghen RL, Lewis SM, Dacie JV, Crookston, JH. HEMPAS: Congenital dyserythropoietic anaemia (type II). $Q J$ Med 1976;42:257-78.

22 Barosi G, Cazzola M, Stefelli M, Ascari I. Studies of ineffective erythropoiesis and peripheral haemolysis in congenital dyserythropoietic anaemia type II. $\mathrm{Br} J$ Haematol 1979;43:243-50.

Requests for reprints to: Dr SR McCann, Department of Clinical Haematology, Trinity Medical School Building, St James's Hospital, Dublin 8. 